\title{
Safety of hexaminolevulinate for blue light cystoscopy in bladder cancer. A combined analysis of the trials used for registration and postmarketing data.
}

\author{
J Alfred Witjes \\ Radboud University, Nijmegen Medical Centre, Nijmegen, Netherlands \\ Leonard G. Gomella \\ Department of Urology, Kimmel Cancer Center, Thomas Jefferson University, 1025 Walnut Street, \\ Philadelphia, PA, 19107, USA \\ Arnulf Stenzl \\ Eberhard-Karls University, Tübingen, Germany

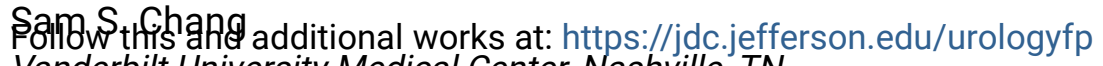 \\ Vanderbilt University Medical Center, Nashville, TN \\ Part of the Urology Commons \\ Pirk.Zaaks know how access to this document benefits you
}

\section{Recommended Citation}

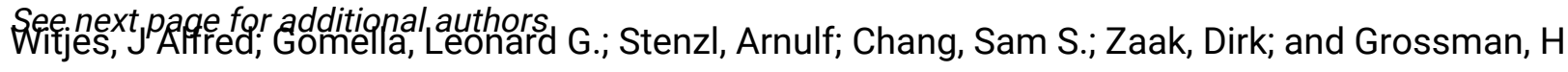
Barton, "Safety of hexaminolevulinate for blue light cystoscopy in bladder cancer. A combined analysis of the trials used for registration and postmarketing data." (2014). Department of Urology Faculty Papers. Paper 24.

https://jdc.jefferson.edu/urologyfp/24

This Article is brought to you for free and open access by the Jefferson Digital Commons. The Jefferson Digital Commons is a service of Thomas Jefferson University's Center for Teaching and Learning (CTL). The Commons is a showcase for Jefferson books and journals, peer-reviewed scholarly publications, unique historical collections from the University archives, and teaching tools. The Jefferson Digital Commons allows researchers and interested readers anywhere in the world to learn about and keep up to date with Jefferson scholarship. This article has been accepted for inclusion in Department of Urology Faculty Papers by an authorized administrator of the Jefferson Digital Commons. For more information, please contact: JeffersonDigitalCommons@jefferson.edu. 


\section{Authors}

J Alfred Witjes, Leonard G. Gomella, Arnulf Stenzl, Sam S. Chang, Dirk Zaak, and H Barton Grossman 
Safety of hexaminolevulinate for blue light cystoscopy in bladder cancer. A combined analysis of the trials used for registration and postmarketing data.

J. Alfred Witjes ${ }^{1}$, Leonard G. Gomella ${ }^{2}$, Arnulf Stenzl ${ }^{3}$, Sam S. Chang ${ }^{4}$, Dirk Zaak ${ }^{5}, \mathrm{H}$. Barton Grossman ${ }^{6}$

1) (corresponding author): Department of Urology, intern mail 659, Radboud University Nijmegen Medical Centre, PO BOX 9101, 6500 HB Nijmegen, The Netherlands. E-mail: f.witjes@uro.umcn.nl

2) Department of Urology, Thomas Jefferson University, Philadelphia, USA

3) Department of Urology, Eberhard-Karls University, Tübingen, Germany

4) Department of Urologic Surgery, Vanderbilt University Medical Center, Nashville, TN, USA

5) Department of Urology, Clinic Traunstein, Traunstein, Germany

6) Department of Urology, The University of Texas MD Anderson Cancer Center, Houston, TX, USA

Abstract word count: 231

Word count: 2,915

Key words: blue light cystoscopy, bladder cancer, safety, toxicity, adverse events. 
Conflict of interest: all authors have worked with Photocure and Ipsen pharmaceuticals as investigators and advisors. 


\section{Summary}

Objectives: To detail and put into perspective safety of hexaminolevulinate blue light cystoscopy (HAL-BLC), including repeated use, based on combined data of controlled trials used for registration of HAL and post-marketing experience. Methods: Safety data of two randomized comparative studies (group 1) and four within patient control studies (group 2) were combined. Post marketing data from $>200,000$ patients were analyzed.

Results: In group 1, 533 patients were examined with HAL-BLC and 499 with white light (WL) cystoscopy. In group 2, 791 patients were examined with both $\mathrm{WL}$ and HAL-BLC. Between $73 \%$ and $93 \%$ of these patients had concomitant diseases. Between $41 \%$ and $58 \%$ of patients had at least one adverse event (AE), although predominantly mild to moderate. The majority was considered as not related to HALBLC and reported in the urinary tract. No SAEs were considered definitely related to HAL-BLC, but in 6 patients serious AEs were of an uncertain relationship. Four possibly related hypersensitivity reactions have been reported. Repeated use did not reveal additional toxicity, also supported by data from three European centers. Conclusions: This combined and detailed analysis of patients from 6 HAL-BLC studies with very comparable criteria shows that HAL-BLC is safe and poses very little additional risks other than expected for WL cystoscopy for bladder tumor resection in this specific patient population. This is supported by 9 years of post marketing experience. Repeated use also seems safe. 


\section{Introduction}

There have been only few new developments in the diagnosis and treatment of bladder cancer in recent decades. For example, in the treatment of non muscleinvasive bladder cancer (NMIBC) Bacille Calmette-Guérin (BCG) was registered in the mid eighties. If therapy was very effective this would not be a major issue. However, recurrence rates in NMIBC are as high as $80 \%$ in high risk patients after some years, thus creating an urgency to improve management [1]. In the last decade blue light cystoscopy (BLC) has become standard of practice in many centres. BLC is done with hexaminolevulinate (HAL), which has been registered for this indication. HAL blue light cystoscopy (BLC) has proven to detect more bladder tumours, enabling a better tumour resection and better patient management. These effects result in a lower short term and long term recurrence rate of NMIBC [2-10]. A recent systemic review showed that $20 \%$ more patients with papillary tumors were detected, and 39\% more CIS patients [2]. This resulted in less residual tumor (odds ratio 0.28 ) and a higher recurrence free survival $(p=0.00002)$. Based on the reduction in long term recurrence rate [10] the registered indication of this drug changed from a pure detection tool to a drug that improves diagnosis and management of bladder cancer patients. The European Association of Urology (EAU) guideline recommends BLC in certain cases of (suspected) NMIBC [11]. In all, the effectiveness of HAL-BLC is clearly proven.

Safety of HAL-BLC has been registered in all studies and BLC with HAL is considered safe and well tolerated. Some of these data have also been reported in the publications of these studies [3-9]. Since a favorable safety profile is an additional reason to embrace on a new drug or technique when improved effectiveness is 
proven, this report specifically addresses the safety of HAL-BLC, including repeated use.

This safety summary provides a review of detailed safety data collected in 6 controlled clinical trials conducted with HAL powder for solution, which were the basis for the FDA approval 2010. Information from post-marketing experience is also presented.

\section{Patients and Methods}

Six controlled studies were used for this safety analyses and review. Details and results of these studies have been published before [3-9]. For all centers in these 6 studies Ethics Committee approval was obtained and for all patients informed consent was obtained. Patient selection and treatment is very similar in all 6 studies. All studies used a single dose HAL 8-mM solution. Cystoscopy was done with the Karl Storz PDD D-light System. In all studies patients had a resection of papillary tumors or biopsies of suspicious area's seen during white light (WL) or BLC. Four studies were within patient control studies (B201/00, B301/01, B302/01, B303/01), so in these studies all patients had HAL-BLC as well as WL cystoscopy. Studies B304/04 and B305/04 were randomized comparative studies, where patients were randomized to have the inspection and transurethral resection of a tumor (TURB) with WL, or HAL-BLC after WL.

Because the six controlled clinical studies were very comparable, safety data were combined to study the safety profile of HAL-BLC in detail in this patient population. AEs definitions and description of baseline voiding were the same throughout the six studies. AEs were assessed from the time of HAL instillation until exit from the study. 
Treatment-emergent adverse events (TEAEs) were defined as those events that occurred or worsened after exposure had begun. For patients in studies B305/04 and B304/04 who were randomized to the standard cystoscopy arms, TEAEs were events that occurred or worsened after the initiation of the standard cystoscopy procedure. AEs considered by the investigator to be related to HAL-BLC with a high degree of certainty or AEs where a relationship to HAL-BLC could not be ruled out are presented together as "related AEs." In the 305 extension study, thirty-nine out of 551 participants (both in the BLC and in the WL group) had multiple HAL instillations after the initial study period. Data on possible anaphylactic reactions with repeated use was collected retrospectively. Postmarketing data from the product approved in 2004 was also analysed.

\section{Results}

\section{Efficacy}

As mentioned above, results of these 6 studies have been published before [3-9]. In short, all 6 studies showed significant increased detection rate with HAL-BLC, especially for CIS. Two studies also looked at recurrence rate as endpoint. Both studies showed an advantage for patients treated with HAL-BLC $[3,4]$.

\section{Safety}

The studies combined for the safety analysis have been grouped as follows: in group 1 patients are included who received HAL-BLC $(n=533)$ or $W L(n=499)$ cystoscopy in studies B305/04 and B304/04. In group 2, 791 patients are included from the 4 older studies (B201/00, B301/01, B302/01, B303/01) in which patients had HAL-BLC after 
WL cystoscopy during the same procedure and anesthesia. In group 1 the median age of the WL study group was 69.5 , compared to 69.0 in the HAL-BLC group. In group 2 median age was 68.5. Patients in all studies were primarily white and the male female ratio was 3.2:1. The patient population appeared homogenous across all six studies. Although the majority of patients had recurrent tumors, most had not received intravesical therapy before.

As expected in a group of bladder cancer patients with advanced age, multiple co morbidities and concomitant medications were noted. In group 1, $86.8 \%$ of patients in the HAL-BLC study group and $73.3 \%$ of patients in the WL study group suffered from ongoing diseases, as compared with $93 \%$ of patients in group 2. Baseline bladder symptoms, noted and registered at study entry, are shown in table 1.

The safety evaluations that were performed in each of the six studies are listed in table 2. Data from individual studies were pooled to create integrated data sets for each of the data domains.

An overview of results in the different groups is presented below. In table 3 the number of $A E s$ is listed, whether the AEs are considered related, the number of $A E s$ leading to treatment discontinuation, the number of SAEs and finally the number of deaths occurring during the study period. AEs per body system are detailed per degree of severity in tables 4 (HAL-BLC versus WL in group 1) and 5 (group 2). As expected, the most frequently involved body system in patients treated for bladder cancer is the urinary tract. The second most frequently involved body organ system was the gastrointestinal tract. AEs based on laboratory changes were rare, usually mild and none was considered related to HAL-BLC. Also no unexpected findings or adverse trends were apparent in vital signs or physical examination findings after treatment with HAL-BLC. No trends for increased toxicity have been noted in patients 
whose instillation time exceeded the 1-hour period in the labeling. Mean HAL retention time was 88.4 minutes (range: 4.0 to 360.0 minutes), and exceeded 180 minutes in 31 patients (table 6).

No SAEs were considered definitively related to HAL-BLC in any clinical study. However, 8 SAEs observed in 6 patients were of an uncertain relationship to HALBLC. Treatment discontinuation due to an AE was reported in $12(0.9 \%)$ of the total of 1,324 patients. In group 1 eight BLC patients and one WL-cystoscopy patient were withdrawn from study participation because of an $\mathrm{AE}$ (considered all serious per protocol), none of which were considered to be related to HAL or WL exposure. In group 2, 3 patients were withdrawn from study participation because of an SAE. Two of these SAEs, in 1 patient, had an uncertain relationship to HAL exposure. For this locally administered product, no apparent drug-drug, drug-food, or drug-disease interactions were observed.

Overall, 21 patients died in these 6 studies (table 3). No deaths were attributable to HAL-BLC.

Repeated use was studied in the long term follow up of controlled trial B305/04 (B305/E10). In the 4.5 years of follow up 29 of 128 European patients randomized to HAL-BLC received repeated HAL from commercial source at a repeat TURB. Thirteen patients had 1 additional TURB with HAL, 8 patients 2 additional HALTURBs and 8 patients underwent $\geq 3$ additional TURBs with HAL. Of the 131 European patients in the WL group, 15 patients underwent 1 additional HAL-TURB, 4 patients underwent 2 additional HA-TURBs and 6 patients underwent $\geq 3$ additional HAL-TURBs. In total 39 patients were exposed to HAL at least twice during the study period. All files were checked retrospectively, and no adverse events suggesting anaphylaxis were found. 


\section{Comment}

AE's into perspective. Although a summary of the AEs in the six individual studies has been presented in the respective publications [3-9], this detailed analysis makes it possible to put the AEs into the perspective of symptoms seen in bladder cancer and this specific older patient cohort. NMIBC is associated with hematuria in $80 \%$ to $90 \%$ of patients [12-14]. Other less frequent signs are urinary frequency, dysuria and pain, and a range of other renal or urinary tract related problems. This is confirmed by data collected at study entry on bladder symptoms, before any manipulation had taken place. As can be seen in table 1, already $20 \%$ to $30 \%$ of patients have symptoms of the urinary tract at presentation. Another potential confounder in bladder cancer patients, which are older and often still smoking, is frequent competing co morbidities and concomitant medication. Indeed, nearly all patients included in this clinical program used a number of concomitant medications. These presenting symptoms and symptoms due to co morbidities should be distinguished from symptoms due to diagnosis, treatment and surveillance of bladder cancer, since obviously invasive procedures like cystoscopy, bladder biopsy, TURB and cauterization can cause similar symptoms. Although this is daily practice for any urologist, literature on quantitative analysis of typical complications occurring after cystoscopy with rigid scopes and biopsies or TURB are very sparse. The complications after flexible cystoscopy are better reported, and even flexible cystoscopy is reported to cause urgency and increased voiding frequency in $35 \%$ to $40 \%$ of patients, and complaints of pain are reported in $20 \%$ to $50 \%$ of patients $[16,17]$. Compared to our study, where rigid cystoscopy and TUR are applied, 
procedural pain and other urinary disorders and are found in approximately $5 \%$ and $25 \%$ after HAL-BLC and WL (table 4), and in $11.9 \%$ and $33.6 \%$ in those patients were HAL-BLC and WL were combined (table 5). Also other symptoms in our study are comparable or less as reported in literature. The frequency of urinary tract infections in our study is comparable to that after cystoscopy only [16-19]. Our overall frequency of hematuria after cystoscopy and TURB was $13.7 \%$, compared to reported gross hematuria after flexible cystoscopy in 19\% [17]. In all, since symptoms after rigid cystoscopy are reported twice as frequent compared to flexible cystoscopy [20], this puts symptoms in our studies in a positive perspective, having used rigid instruments in all studies.

Type of AE's and relation to the procedure. Most frequent AEs were renal and urinary disorders as expected [21], followed by gastro-intestinal AEs, procedural pain and urinary tract infection. Type and frequency of AEs were comparable between HALBLC and WL cystoscopy in the two randomized studies and more frequently reported when BLC and WL cystoscopy were combined. Most of these AEs were mild to moderate. In patients receiving HAL-BLC, $79.8 \%$ of side effects had an onset during or after the cystoscopic examination and were unrelated to HAL-BLC, which is given more than one hour earlier. Similarly, in the WL study group, $87.2 \%$ AEs occurred during or after the cystoscopic examination. Overall, HAL instillation was associated with a low incidence of AEs that were considered by the investigator to be related to the study product (table 3). The percentage of SAEs was somewhat different between groups. The WL group in group 1 was in between these groups. SAEs were uncommon and none were definitely related to HAL-BLC. Treatment discontinuation due to an $\mathrm{AE}$ was also uncommon $(0.9 \%)$ and not considered to be related to HAL 
exposure, except two AEs in one patient where the relationship with HAL-BLC was considered uncertain. Overall, 21 patients died in these 6 studies which was expected in view of the population of elderly patients with multiple concomitant diseases.

In all, when compared with the AE data in the WL study group, and considering baseline bladder cancer symptoms, concomitant disorders and discomfort due to the treatment, the analysis of the AE data in the HAL-BLC study group does not indicate significant risk beyond the current standard of care. The difference between group 1 and group 2 is likely due to the fact that in the initial 4 studies patients had a WL cystoscopy followed by BLC. This results in an overall longer procedural time.

$B L C$ and concomitant disorders. Although there was a high prevalence of cardiovascular disease in the studied population (51.4\% of HAL-BLC patients and 47.1\% WL-cystoscopy patients presented with ongoing vascular disorders and $30.8 \%$ of HAL-BLC and $27.1 \%$ WL-cystoscopy with ongoing cardiac disorders at baseline), there were no findings to indicate that HAL-BLC contributed to cardiovascular risk in individual patients.

With regard to laboratory changes these were uncommon and predominantly mild. An increase in white blood cell counts might very well be a sign of urinary tract infection due to the procedure or even a reactive rise due to the procedure itself. Anemia obviously can be secondary to some bleeding after TURB. Slight decreases in hemoglobin may also be caused by an increased plasma volume in patients who were fasting and slightly dehydrated before the procedure and were rehydrated after the procedure. Although reported in other studies [22], we found no relationship between demographic factors and AEs. Finally the absence of increased toxicity in 
case of higher or longer exposure to the drug and the safety profile in the post marketing period confirms the safety profile of HAL-BLC.

Repeated use. An interesting issue is the repeated use of HAL. Repeated use of HAL can be expected and is done because of the fact that NMIBC frequently recurs, with subsequent repeated TURB's. Prospective information on this issue is not available, but it has been studied retrospectively in 39 European patients in the long term follow up study B305/E10 where no adverse events suggesting anaphylaxis were found. Additionally, collection of data from 3 hospitals which have used HAL repeatedly (University Hospital, Tübingen, Germany, University Hospital, Regensburg, Germany and Guy's Hospital, London, UK), showed no anaphylactic reactions via the post marketing reporting system (personal communication). The system contains data on 917 patients, $210(23 \%)$ of which had more than one, and $70(8 \%)$ had more than two and up to six instillations of HAL during diagnosis and follow up of their bladder cancer. Finally, postmarketing_experience reflects the experience in more than 200,000 procedures with HAL-BLC over an 9 year period in 28 European countries and now in the USA. Between September 17, 2004 and June 12, 2013, there were a total of 27 reports of adverse drug reactions that have been received by the Marketing Authorization Holders. For two reported anaphylactoid reactions and two other cases of possible hypersensitivity reactions, a causal role of HAL-BLC could not be ruled out. Both reported anaphylactic reactions were in patients that had their first HAL instillation. The first report was in a 69 year old male. Five hours after the instillation, which had a 3 hours retention time, he experienced a fall in blood pressure, urticaria, chest pressure, swelling of the throat and atrial fibrillation. His serum tryptase (a marker of mast cell activation) increased 9 times, and later his skin 
test was positive to $\mathrm{HAL}$ in duplicate. The mechanism remains uncertain, but it was reported to be likely a non IgE mediated allergic reaction caused by $H A L$ [23]. A second event was a spontaneous report of an anaphylactoid shock in a 71 year old male. Within 2 minutes, hypotension and exanthema developed, with a subsequent coronary event due to the hypotension. He had a negative IgE enzyme immunoassay test to concomitant ATB, and his serum tryptase was normal, although done 5 days later. Whether this reaction was due to HAL-BLC or anesthetic medication remains unclear. The other reported adverse reactions were attributed to manifestations of underlying diseases or procedural complications.

Limitations. A limitation of this study might be that data from six individual trials were combined. However, patient selection, characteristics and treatment, including the HAL-BLC procedure, were very similar throughout the six studies. Also, registration and definition of AEs remained the same. Indeed, the six individual datasets showed comparable adverse event spectra. Laboratory changes, vital signs and physical examination were not registered in all trials, but since they were uncommon and predominantly mild, it seems unlikely that more data would have given another spectrum of abnormalities.

\section{Conclusion}

In addition to the already published safety data of the six individual studies, the detailed analysis on safety of this large combined data set, enhanced by 8 years of post marketing experience, shows that HAL-BLC is safe and well tolerated and poses very little additional risks in patients with known or suspected bladder cancer. 
There were no signs that HAL-BLC contributed to the frequency or severity of AEs, other than what could be expected for WL cystoscopy, for TURB procedures and in this patient population. Except for 4 possible cases of hypersensitivity reactions, no particular clusters of any particular post marketing reactions have been received. Repeated use also seems safe. On the other hand there is little discussion on the improved patient's outcome after HAL TURB. This suggests a positive medical risk benefit ratio, which might stand up to other strategies to improve patient's outcome with intravesical drug therapy. 


\section{References}

1. Sylvester RJ, van der Meijden APM, Oosterlinck W, et al. Predicting Recurrence and Progression in Individual Patients with Stage Ta T1 Bladder Cancer Using EORTC Risk Tables: A Combined Analysis of 2596 Patients from 7 EORTC Trials. Eur Urol 2006;49:466-77

2. Kausch I, Sommerauer M, Montorsi F, et al. Photodynamic diagnosis in nonmuscle-invasive bladder cancer: a systematic review and cumulative analysis of prospective studies. Eur Urol. 2010;57:595-606.

3. Stenzl A, Burger M, Fradet $Y$, et al. Hexaminolevulinate guided fluorescence cystoscopy reduces recurrence in patients with nonmuscle invasive bladder cancer. $\mathrm{J}$ Urol. 2010;184:1907-13.

4. Hermann GG, Mogensen K, Carlsson S, et al. Fluorescence-guided transurethral resection of bladder tumours reduces bladder tumour recurrence due to less residual tumour tissue in Ta/T1 patients: a randomized two-centre study. BJU Int. 2011;108(8 Pt 2):E297-303.

5. Jichlinski P, Guillou L, Karlsen SJ, et al. Hexyl aminolevulinate fluorescence cystoscopy: new diagnostic tool for photodiagnosis of superficial bladder cancer--a multicenter study. J Urol. 2003;170:226-9.

6. Schmidbauer J, Witjes F, Schmeller N, et al. Improved Detection of Urothelial Carcinoma In Situ With Hexaminolevulinate Fluorescence Cystoscopy. J Urol. $2004 ; 171: 135-138$

7. Grossman HB, Gomella L, Fradet Y, et al. A phase III, multicenter comparison of hexaminolevulinate fluorescence cystoscopy and white light cystoscopy for the detection of superficial papillary lesions in patients with bladder cancer. J Urol. 2007;178:62-7

8. Fradet Y, Grossman HB, Gomella L, et al. PC B302/01 Study Group. A comparison of hexaminolevulinate fluorescence cystoscopy and white light cystoscopy for the detection of carcinoma in situ in patients with bladder cancer: a phase III, multicenter study. J Urol. 2007;178:68-73

9. Jocham D, Witjes F, Wagner S, et al. Improved detection and treatment of bladder cancer using Hexvix® imaging: a prospective Phase III multi-centre study. J Urol 2005; $174: 862-6$

10. Grossman HB, Stenzl A, Fradet Y, et al. Long-term decrease in bladder cancer recurrence with hexaminolevulinate enabled fluorescence cystoscopy. J Urol 2012;188:58-62

11. Babjuk M, Oosterlinck W, Sylvester R, et al. EAU guidelines on non-muscleinvasive urothelial carcinoma of the bladder, the 2011 update. Eur Urol. 2011;59:9971008. 
12. Scher HI, Motzer RJ. Bladder and renal cell cancer. Kasper DL, ed. In: Harrison's Principles of Internal Medicine. 16th edition, New York: McGraw-Hill; 2005:539-943.

13. Bock R. Cancer of the bladder. Research report. National Cancer Institute, Office of Cancer Communications; Bethesda, MD.

14. Pashos CL, Botteman MF, Laskin BL, et al. Bladder cancer: epidemiology, diagnosis, and management. Cancer Pract. 2002;10(6):311-322.

15. Shaw GL, Bunce CJ. Fluorescence cystoscopy - how to do it. Photodiagnosis Photodyn Ther. 2008;5(4):267-270.

16. Kortmann BB, Sonke GS, D'Ancona FC, et al. The tolerability of urodynamic studies and flexible cysto-urethroscopy used in the assessment of men with lower urinary tract symptoms. BJU Int. 1999;84(4):449-453.

17. Burke DM, Shackley DC, O'Reilly PH. The community-based morbidity of flexible cystoscopy. BJU Int. 2002;89(4):347-349.

18. Almallah YZ, Rennie CD, Stone J, et al. Urinary tract infection and patient satisfaction after flexible cystoscopy and urodynamic evaluation. Urology. 2000;56(1):37-39.

19. Clark KR, Higgs MJ. Urinary infection following out-patient flexible cystoscopy. $\mathrm{Br}$ J Urol. 1990;66(5):503-505.

20. Denholm SW, Conn IG, Newsam JE, et al. Morbidity following cystoscopy: comparison of flexible and rigid techniques. $\mathrm{Br} J$ Urol. 1990;66(2):152-154.

21. The U.S. National LIbrary of Medicine and the National Institutes of Health, Bladder cancer. Medline Plus, Available at: http://www.nlm.nih.gov/medlineplus/ency/article/000486.htm. Accessed 20 April 2009.

22. Madeb R, Messing EM. Gender, racial and age differences in bladder cancer incidence and mortality. Urol Oncol. 2004;22(2):86-92.

23. Colapaoli, Thorsen J, Nopp A, et al. A case of anaphylactic shock possibly caused by intravesical Hexvix. Acta Anaesthesiol Scand $2006 ; 50: 1165-7$ 
Table 1: Bladder symptoms at study entry in the safety set, when recorded.

\begin{tabular}{|c|c|c|c|}
\hline & \multicolumn{2}{|l|}{ Group 1} & \multirow{2}{*}{$\begin{array}{l}\text { Group } 2 \\
\text { HAL (n=791) } \\
n(\%)\end{array}$} \\
\hline & $\begin{array}{l}\text { HAL }(n=533) \\
n(\%)\end{array}$ & $\begin{array}{l}\text { WL (n=499) } \\
n(\%)\end{array}$ & \\
\hline \multicolumn{4}{|c|}{ Hematuria } \\
\hline Yes & $48(9.0 \%)$ & $34(6.8 \%)$ & $134(16.9 \%)$ \\
\hline No & $372(69.8 \%)$ & $346(69.3 \%)$ & $655(82.8 \%)$ \\
\hline Missing & $0(0.0 \%)$ & $0(0.0 \%)$ & $2(0.3 \%)$ \\
\hline \multicolumn{4}{|c|}{ Painful urination } \\
\hline Yes & $21(3.9 \%)$ & $17(3.4 \%)$ & $60(7.6 \%)$ \\
\hline No & $399(74.9 \%)$ & $363(72.7 \%)$ & $729(92.2 \%)$ \\
\hline Missing & $0(0.0 \%)$ & $0(0.0 \%)$ & $2(0.3 \%)$ \\
\hline \multicolumn{4}{|c|}{ Frequent Urination or the Urge to Urinate, but without Results } \\
\hline Yes & $45(8.4 \%)$ & $46(9.2 \%)$ & $158(20.0 \%)$ \\
\hline No & $374(70.2 \%)$ & $334(66.9 \%)$ & $631(79.8 \%)$ \\
\hline Missing & $1(0.2 \%)$ & $0(0.0 \%)$ & $2(0.3 \%)$ \\
\hline
\end{tabular}


Table 2. Safety evaluations performed per study

\begin{tabular}{|l|l|l|l|l|l|l|}
\hline Evaluations & $\mathrm{B} 201 / 00$ & $\mathrm{~B} 301 / 01$ & $\mathrm{~B} 302 / 01$ & $\mathrm{~B} 303 / 01$ & $\mathrm{~B} 304 / 04$ & $\mathrm{~B} 305 / 04$ \\
\hline Adverse events & $\mathrm{X}$ & $\mathrm{X}$ & $\mathrm{X}$ & $\mathrm{X}$ & $\mathrm{X}$ & $\mathrm{X}$ \\
\hline $\begin{array}{l}\text { Hematology and } \\
\text { biochemistry }^{\dagger}\end{array}$ & $\mathrm{X}$ & $\mathrm{X}$ & $\mathrm{X}$ & & & \\
\hline Vital signs $^{\ddagger}$ & & $\mathrm{X}$ & $\mathrm{X}$ & $\mathrm{X}$ & & $\mathrm{X}$ \\
\hline Physical examination $^{\ddagger}$ & & $\mathrm{X}$ & $\mathrm{X}$ & $\mathrm{X}$ & & $\mathrm{X}$ \\
\hline $\begin{array}{l}\text { Concomitant } \\
\text { medications }^{\S}\end{array}$ & $\mathrm{X}$ & $\mathrm{X}$ & $\mathrm{X}$ & $\mathrm{X}$ & $\mathrm{X}$ & $\mathrm{X}$ \\
\hline
\end{tabular}

Adverse events were monitored throughout the study.

$\dagger$ Blood samples were collected before Hexvix instillation and at 24 hours after.

‡ Evaluations were performed before Hexvix instillation and at 24 hours after.

$\S$ Concomitant medications were monitored and recorded throughout the followup phase of each study. 
Table 3: Overview of AEs experienced in the 6 controlled studies (safety set)

\begin{tabular}{|l|l|l|l|}
\hline & \multicolumn{2}{l|}{ Group 1 } & Group 2 \\
\cline { 2 - 4 } & $\begin{array}{l}\text { HAL } \\
\text { N = 533 }\end{array}$ & $\begin{array}{l}\text { WL } \\
\mathbf{N = 4 9 9}\end{array}$ & $\begin{array}{l}\text { HAL } \\
\text { N = 791 }\end{array}$ \\
\hline Total number of unique AEs & 599 & 494 & 1,181 \\
\hline Patients with at least one AE (n [\%]) & $\begin{array}{l}232 \\
(43.5 \%)\end{array}$ & $\begin{array}{l}204 \\
(40.9 \%)\end{array}$ & $457(57.8 \%)$ \\
\hline $\begin{array}{l}\text { Total number of unique related } \\
\text { AEs }\end{array}$ & 56 & 1 & 232 \\
\hline $\begin{array}{l}\text { Patients with at least one related AE } \\
\text { (n [\%]) }\end{array}$ & $38(7.1 \%)$ & $1(0.2 \%)$ & $123(15.5 \%)$ \\
\hline $\begin{array}{l}\text { Total number of unique AEs leading } \\
\text { to discontinuation }\end{array}$ & 8 & 1 & 4 \\
\hline $\begin{array}{l}\text { Patients with at least one AE } \\
\text { leading to discontinuation (n [\%]) }\end{array}$ & $8(1.5 \%)$ & $1(0.2 \%)$ & $3(0.4 \%)$ \\
\hline Total number of unique SAEs & 63 & 47 & 57 \\
\hline $\begin{array}{l}\text { Patients with at least one SAE (n } \\
\text { [\%]) }\end{array}$ & $51(9.6 \%)$ & $36(7.2 \%)$ & $47(5.9 \%)$ \\
\hline $\begin{array}{l}\text { Deaths occurring during the study } \\
\text { period }\end{array}$ & $10(1.9 \%)$ & $4(0.8 \%)$ & $7(0.9 \%)$ \\
\hline \hline
\end{tabular}

Note: Patients with multiple AEs under one preferred term or body system are counted only once in the most severe category for that preferred term or body system. If one event is related to exposure and another is not related, the related $A E$ is counted. 
Table 4. Summary of most frequent AEs by severity in group 1

\begin{tabular}{|c|c|c|c|c|c|c|c|c|}
\hline \multirow[b]{2}{*}{$\begin{array}{l}\text { MedDRA Body } \\
\text { System } \\
\text { Preferred Term }\end{array}$} & \multicolumn{4}{|c|}{ HAL, $N=533$} & \multicolumn{4}{|c|}{ WL, N = 499} \\
\hline & $\begin{array}{l}\text { Mild } \\
\mathrm{n}(\%)\end{array}$ & $\begin{array}{l}\text { Moderat } \\
\text { e, n (\%) }\end{array}$ & $\begin{array}{l}\text { Seve } \\
\text { re, n } \\
(\%) \\
\end{array}$ & $\begin{array}{l}\text { Sum } \\
\mathrm{n}(\%)\end{array}$ & $\begin{array}{l}\text { Mild } \\
\text { n (\%) }\end{array}$ & $\begin{array}{l}\text { Modera } \\
\text { te, } \mathrm{n} \%)\end{array}$ & $\begin{array}{l}\text { Sever } \\
\text { e, } \\
\mathrm{n}(\%) \\
\end{array}$ & $\begin{array}{l}\text { Sum } \\
\mathrm{n}(\%)\end{array}$ \\
\hline $\begin{array}{l}\text { Total number of } \\
\text { unique AEs occurring } \\
\text { in at least } 1 \% \text { of the } \\
\text { safety set across } \\
\text { studies }\end{array}$ & 201 & 145 & 15 & 361 & 176 & 113 & 5 & 294 \\
\hline $\begin{array}{l}\text { Patients with at least } \\
\text { one } A E\end{array}$ & $\begin{array}{l}77 \\
(14.4 \% \\
\end{array}$ & $\begin{array}{l}87 \\
(16.3 \%)\end{array}$ & $\begin{array}{l}15 \\
(2.8 \\
\%)\end{array}$ & $\begin{array}{l}179 \\
(33.6 \% \\
\end{array}$ & $\begin{array}{l}84 \\
(16.8 \% \\
\end{array}$ & $\begin{array}{l}71 \\
(14.2 \%)\end{array}$ & $\begin{array}{l}5 \\
(1.0 \% \\
)^{2}\end{array}$ & $\begin{array}{l}160 \\
(32.1 \\
\%)\end{array}$ \\
\hline $\begin{array}{l}\text { Gastrointestinal } \\
\text { disorders }^{*}\end{array}$ & $\begin{array}{l}24 \\
(4.5 \%)\end{array}$ & $\begin{array}{l}11 \\
(2.1 \%)\end{array}$ & $\begin{array}{l}1 \\
(0.2 \\
\%)\end{array}$ & $\begin{array}{l}36 \\
(6.8 \%)\end{array}$ & $\begin{array}{l}21 \\
(4.2 \%)\end{array}$ & $\begin{array}{l}12 \\
(2.4 \%)\end{array}$ & $\begin{array}{l}1 \\
(0.2 \% \\
)^{2}\end{array}$ & $\begin{array}{l}34 \\
(6.8 \% \\
\end{array}$ \\
\hline Urinary tract infection & $\begin{array}{l}16 \\
(3.0 \%)\end{array}$ & $\begin{array}{l}11 \\
(2.1 \%)\end{array}$ & $\begin{array}{l}1 \\
(0.2 \\
\%)\end{array}$ & $\begin{array}{l}28 \\
(5.3 \%)\end{array}$ & $\begin{array}{l}15 \\
(3.0 \%)\end{array}$ & $\begin{array}{l}10 \\
(2.0 \%)\end{array}$ & $\begin{array}{l}0 \\
(0.0 \% \\
)^{2}\end{array}$ & $\begin{array}{l}25 \\
(5.0 \% \\
\end{array}$ \\
\hline Procedural pain & $\begin{array}{l}13 \\
(2.4 \%)\end{array}$ & $\begin{array}{l}15 \\
(2.8 \%)\end{array}$ & $\begin{array}{l}0 \\
(0.0 \\
\%)\end{array}$ & $\begin{array}{l}28 \\
(5.3 \%)\end{array}$ & $\begin{array}{l}13 \\
(2.6 \%)\end{array}$ & $\begin{array}{l}7 \\
(1.4 \%)\end{array}$ & $\begin{array}{l}0 \\
(0.0 \% \\
)^{2}\end{array}$ & $\begin{array}{l}20 \\
(4.0 \% \\
\end{array}$ \\
\hline $\begin{array}{l}\text { Renal and urinary } \\
\text { disorders }{ }^{* \star}\end{array}$ & $\begin{array}{l}63 \\
(11.8 \% \\
\end{array}$ & $\begin{array}{l}62 \\
(11.6 \%)\end{array}$ & $\begin{array}{l}12 \\
(2.3 \\
\%)\end{array}$ & $\begin{array}{l}137 \\
(25.7 \% \\
\end{array}$ & $\begin{array}{l}61 \\
(12.2 \% \\
\end{array}$ & $\begin{array}{l}52 \\
(10.4 \%)\end{array}$ & $\begin{array}{l}4 \\
(0.8 \% \\
\end{array}$ & $\begin{array}{l}117 \\
(23.4 \\
\%)\end{array}$ \\
\hline
\end{tabular}

* Including abdominal pain, constipation, diarrhea, nausea and vomiting

** including bladder pain, bladder perforation, bladder spasm, dysuria, hematuria, micturition urgency, pollakiuria and urinary retention 
Table 5 Summary of most frequent AEs in group 2

\begin{tabular}{|c|c|c|c|c|}
\hline \multirow{3}{*}{$\begin{array}{l}\text { MedDRA Body System } \\
\text { Preferred Term }\end{array}$} & \multicolumn{4}{|l|}{ Group 2* } \\
\hline & \multicolumn{4}{|l|}{ HAL, N = 791} \\
\hline & $\begin{array}{l}\text { Mild } \\
\text { n (\%) }\end{array}$ & \begin{tabular}{|l|} 
Moderate \\
n (\%)
\end{tabular} & $\begin{array}{l}\text { Severe } \\
\mathrm{n}(\%)\end{array}$ & $\begin{array}{l}\text { Sum } \\
\mathrm{n}(\%)\end{array}$ \\
\hline $\begin{array}{l}\text { Total number of unique } \\
\text { AEs occurring in at least } \\
1 \% \text { of the safety set } \\
\text { across studies }\end{array}$ & 483 & 271 & 28 & 782 \\
\hline $\begin{array}{l}\text { Patients with at least } \\
\text { one } A E\end{array}$ & $211(26.7 \%)$ & \begin{tabular}{|l|}
161 \\
$(20.4 \%)$ \\
\end{tabular} & $\begin{array}{l}26 \\
(3.3 \%)\end{array}$ & 398 (50.3\%) \\
\hline $\begin{array}{l}\text { Gastrointestinal } \\
\text { disorders }\end{array}$ & $56(7.1 \%)$ & \begin{tabular}{|l|}
36 \\
$(4.6 \%)$ \\
\end{tabular} & $2(0.3 \%)$ & $94(11.9 \%)$ \\
\hline Urinary tract infection & $12(1.5 \%)$ & $9(1.1 \%)$ & $1(0.1 \%)$ & $22(2.8 \%)$ \\
\hline Procedural pain & $59(7.5 \%)$ & $34(4.3 \%)$ & $1(0.1 \%)$ & $94(11.9 \%)$ \\
\hline $\begin{array}{l}\text { Renal and urinary } \\
\text { disorders }{ }^{* *}\end{array}$ & $158(20.0 \%)$ & $91(11.5 \%)$ & $\begin{array}{l}17 \\
(2.1 \%)\end{array}$ & $266(33.6 \%)$ \\
\hline
\end{tabular}

* Including abdominal pain, constipation, diarrhea, nausea and vomiting

** including bladder pain, bladder perforation, bladder spasm, dysuria, hematuria, micturition urgency, pollakiuria and urinary retention 
Table 6: HAL mean retention times

\begin{tabular}{||l|l|l||}
\hline $\begin{array}{l}\text { Study } \\
\text { reference] }\end{array}$ & $\begin{array}{l}\text { Mean retention time in minutes }(\mathrm{min} \\
\text { and max) }\end{array}$ & Patient number \\
\hline \hline B201/00 [5] & $86.2(45-229)$ & 52 \\
\hline B301/01 [6] & $85.7(5-343)$ & 278 \\
\hline B302/01 [7,8] & $87.0(34-210)$ & 297 \\
\hline B303/01 [9] & $82.4(10-360)$ & 162 \\
\hline B304/04 [4] & $102.7(12-303)$ & 109 \\
\hline B305/04 [3] & $90.3(4-255)$ & 410 \\
\hline
\end{tabular}

